\title{
多孔質・柔軟工作物の工妙加工
}

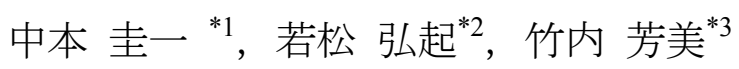

\section{Dexterous machining of porous and soft objects}

\author{
Keiichi NAKAMOTO*1 ${ }^{*}$ Hiroki WAKAMATSU ${ }^{* 2}$ and Yoshimi TAKEUCHI ${ }^{* 3}$ \\ ${ }^{* 1}$ Department of Mechanical Systems Engineering, Tokyo University of Agriculture and Technology \\ 2-24-16 Naka-cho, Koganei-shi, Tokyo 184-8588, Japan \\ ${ }^{* 2}$ Department of Applied Biological Chemistry, Tokyo University of Agriculture and Technology \\ 3-5-8 Saiwai-cho, Fuchu-shi, Tokyo 183-8509, Japan \\ ${ }^{*}$ Department of Mechanical Engineering, Chubu University \\ 1200 Matsumoto-cho, Kasugai-shi, Aichi 487-8501, Japan
}

\section{Received 15 December 2014}

\begin{abstract}
In manufacturing industries, a demand for high value-added products has been increasing. It is important to establish a new way of creating value-added products, such as craftwork objects or applied arts, different from traditional way of achieving high quality and low price. Such a machining technology that enables (1) extremely complex or small shape generation, (2) machining of hard or soft materials, and (3) machining of difficult-to-grasp or fix workpiece may be called "Dexterous Machining". Previously, "Dexterous Machining" is proposed for soft objects such as rubber by employing an aqueous solution of sodium acetate to fix a workpiece and to improve the stiffness. However, the method has not been applied to porous and soft objects like sponge. Porous and soft objects are much more difficult to machine compared to non-porous ones due to their inner numerous holes. Thus, the study deals with the first trial of machining the porous and soft objects without specific equipment. As a result of conducted experiments, it is found that a impregnation of the aqueous solution of sodium acetate is able to be applied to precisely machine porous and soft objects. These results expanded the potential of usage of the aqueous solution of sodium acetate and "Dexterous Machining" of porous and soft objects.
\end{abstract}

Key words : Dexterous machining, Porus objects, Soft objfects, CAM, Cutting, Jig and fixture

\section{1. 緒 言}

次世代の工作機械には，熟練者の技能を取り込み，それを自動化技術で巧みに製造する「巧妙加工」という概 念が求められる. この巧妙加工には，(1)非常に複雑な形状を加工寸ること，(2)把持や保持をすることが極度に困 難なものを加工すること，(3)非常に硬い，あるいは柔らかい材料を加工すること，(4)そのままでは非常に不安定 である形状を加工すること，などが含まれる.

最初の項目の非常に複雑な形状を創成するという課題に対しては，5軸制御機能をもつ複合加工機を活用して， 曲がった複数の円柱を加工すること（夏目他，2012）や中空の立方体内に球形を創成すること（濱田他，2011） を試みて成果を得た。また続く項目である把持や保持の難しい材料においては，酶酸ナトリウム水溶液の過冷却 状態からの急速な凝固現象を利用し，ゴムなどの柔軟工作物の把持，見かけ上の剛性確保を可能にし，巧妙加工 の適用範囲を拡大した（中本他, 2013）。そこで本研究では, 巧妙加工を柔軟かつ多孔質の材料へも適用するこ とを目的とする.

スポンジなどの内部に無数の細孔をもつ柔軟材料は，衝撃吸収性，吸音性，吸水性などの優れた性質を有する ことから幅広く利用されており，無孔質柔軟材と同様に，金型で成形されるのが一般的である，一方，多品種少

\footnotetext{
No.14-00680 [DOI:10.1299/transjsme.14-00680], J-STAGE Advance Publication date : 27 March, 2015

*1 正員, 東京農工大学大学院 工学研究院（干184-8588 東京都小金井市中町 2-24-16)

*2 東京農工大学大学院 農学府（干183-8509 東京都府中市幸町 3-5-8）

*3 正員, フェロー, 中部大学 工学部（干487-8501 愛知県春日井市松本町 1200)

E-mail of corresponding author: nakamoto@cc.tuat.ac.jp
} 
量生産においては，取り扱える材質の種類の多さ，創成できる形状の自由度の高さなどから，切削加工が効率的 であり，リードタイム短縮が重要である製品開発においては試作などでの活用も期待できる。しかし，工作物の 把持や切削力に起因する誤差が無孔質材よりも生じやすく, 多孔質材の切削加工は困難である. そこで，これら 多孔質材にも応用できる把持・保持手法の開発が，高精度加工の達成に不可欠である.

柔軟な工作物の切削加工に関しては, 工作物を極低温で凍結させて剛性を確保する手法 (Kakinuma, et al., 2012) や，工作物形状に応じた複数の支持具を積層造形法で作成する手法（寺本他, 2009), 低融点金属を用いた治具の 作成（小原他, 2003）などが，これまでにも提案されてきた. しかし，それらのような外部からの把持や保持とい うアプローチは，内部に大小様々な孔が無数に存在する多孔質材には不向きである.

そこで本報では，著者らが提案した酢酸ナトリウム水溶液を用いた工作物把持手法を応用し，多孔質かつ柔軟 な材料の内部からの保持によって, 目標形状通りの高精度加工を達成する手法を提案する. また併せて, 提案手 法による加工実験の結果を報告する，本手法では，特殊な工具や治具，装置の必要はなく，簡便に多孔質・柔軟 工作物に対する切削加工の課題を解決できる.

\section{2. 酢酸ナトリウム水溶液による多孔質・柔軟工作物の保持}

著者らが提案した酶酸ナトリウム水溶液を用いた工作物把持手法では, 酶酸ナトリウム水溶液の過冷却状態か らの急速な凝固現象を利用して柔軟工作物の把持を実現した（中本他，2013）. 図 1 のように水平な工作機械テ ーブル上に容器を置き, その中に過冷却状態の水溶液と工作物を入れる. 刺激を与え工作物の周りの水溶液を固 体化することで, 複雑形状であったとしても均一な把持力が得られる. 本手法では, 実加工中に䣷酸ナトリウム で実現した把持具もともに削り取っていくこことき，把持具の一部が失われることで工作物の見かけ上の剛性 が変化し, 加工誤差に影響を与えるが, 再度䣷酸ナトリウム水溶液の凝固と融解を繰り返すことで, 必要に応じ た把持が可能であり，十分な加工精度が確保できる.

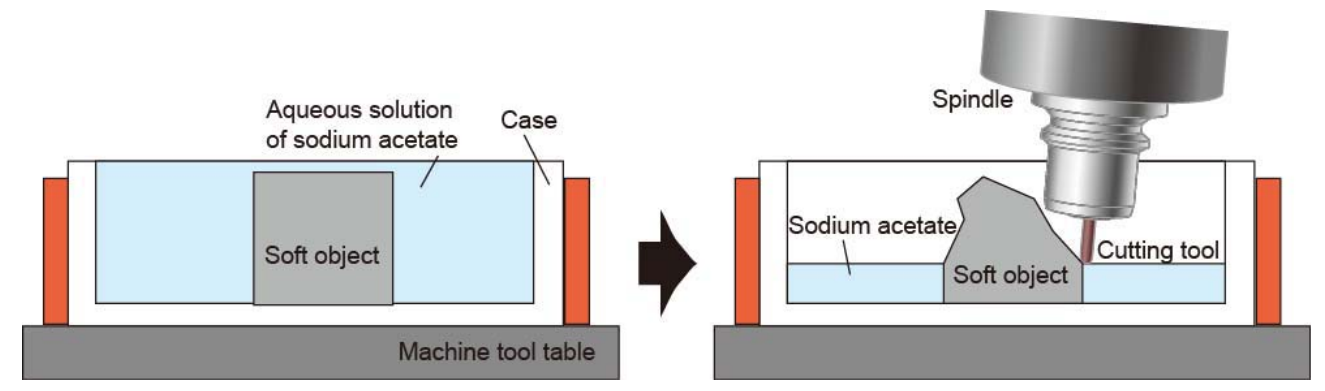

Fig. 1 Soft object machining using sodium acetate (Nakamoto, et al., 2013)

一般的に，柔軟工作物は切削加工に不利な点を多く有する．特に工作物の弾性率が低いことから発生する問題 として, 把持力による変形, 切削力による変形という 2 つ大きな課題が挙げられる. 本研究で対象とする多孔 質・柔軟工作物も，無孔質の柔軟工作物と同様に上記の課題を抱える.これに加えて，多孔質材は内部に無数の 細孔を持つため, 既に提案した外部からの工作物把持手法を用いても, 工作物のみかけ上の剛性を保てず図 2 の ように高精度な加工が困難である。

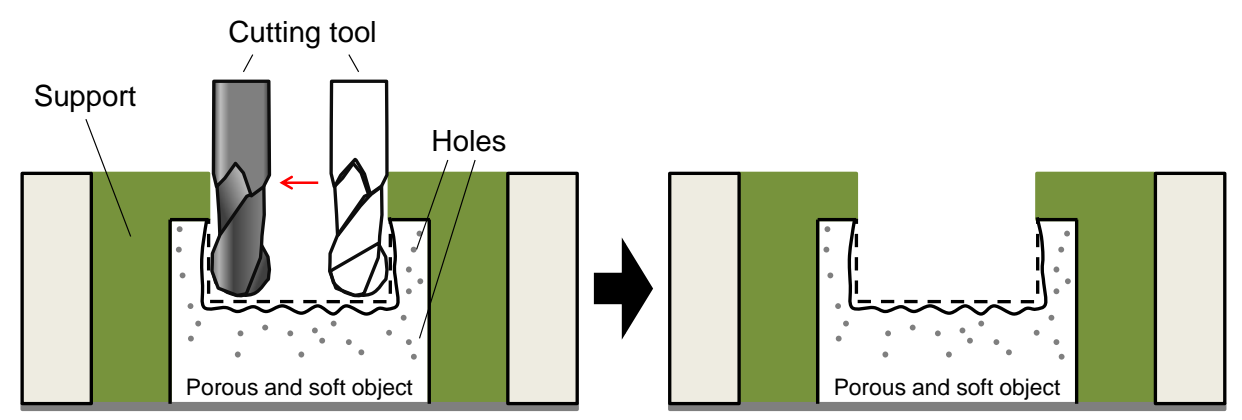

Fig. 2 Influence of cutting force to deformation of porous and soft object 
そこで本研究では，酢酸ナトリウム水溶液が多孔質柔軟材の内部へ浸潤することを利用して多孔質柔軟材の保 持とみかけ上の剛性の確保を実現する。この手法では，これまでに提案した把持手法と同様に水平な工作機械テ ーブル上に容器を置き, その中に水溶液と工作物を入れる。 ここで, 図 3 のように多孔質柔軟材を圧縮し, 内部 に気泡が残らないように䣷酸ナトリウム水溶液を吸収させる，その後，常温で酢酸ナトリウム水溶液に刺激を与 え，容器内の水溶液と共に多孔質柔軟材を固化させる.

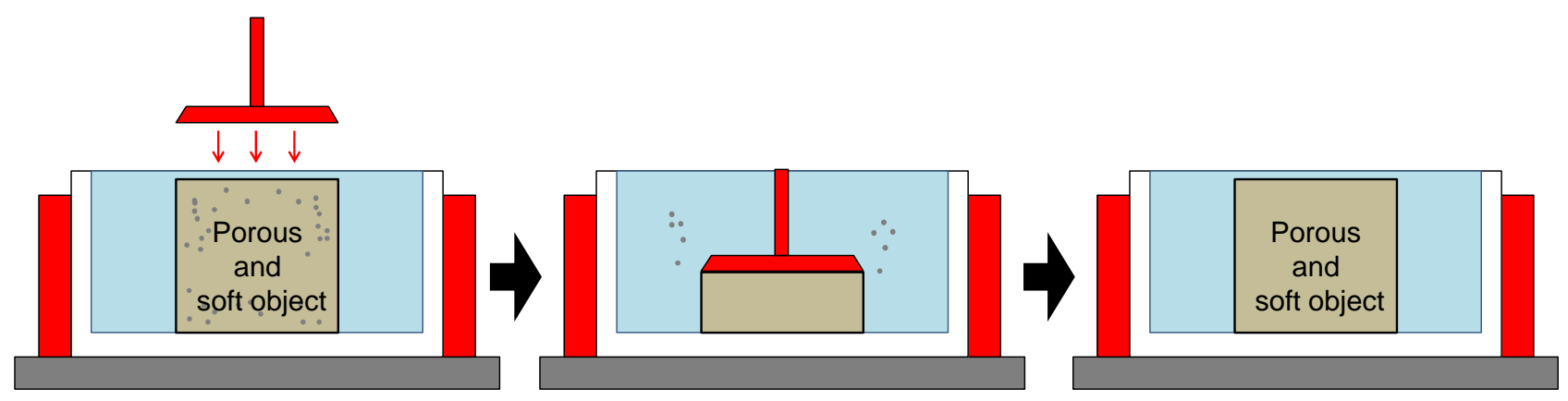

Fig. 3 Impregnation of sodium acetate by compression

\section{3. 多孔質・柔軟工作物保持手法の検証}

表 1 の物性を持つポリエステル系ウレタンフォームを用い，卓上 5 軸加工機（ユニテックシステム：巧み君） で切削加工し, 多孔質・柔軟工作物の保持手法の効果を検証した. 加工条件は表 2 のように設定した. ウレタン フォームの形状は 75 x 75x $50 \mathrm{~mm}$ であり，ここから高さ $8 \mathrm{~mm}$ で厚さ $1 \mathrm{~mm}$ と $2 \mathrm{~mm}$ の長方形の壁を加工した.

ここではまず，図4(a)のように固定したウレタンフォームを(b)(c)のように片側ずつ順にエンドミル加工して高 さ8 mmの壁形状を残した．また本実験では，工具回転方向がダウンカットとなるように加工した場合と，アップ カットとなるように加工した場合だけでなく，比較のため提案する保持法を用いない場合の壁も加工した.

Table 1 Physical propaties of used polyurethane foam

\begin{tabular}{c|c}
\hline Apparent Density $\left[\mathrm{kg} / \mathrm{m}^{3}\right]$ & $22 \pm 2$ \\
\hline Impact resilience [\%] & $42 \leqq$ \\
\hline Hardness [N] & $110 \pm 23$ \\
\hline Number of cells [pcs $/ 25 \mathrm{~mm}]$ & $35 \leqq$ \\
\hline Tensile strength [kPa] & $70 \leqq$ \\
\hline Elongation [\%] & $120 \leqq$ \\
\hline Compression set [\%] & $6 \leqq$ \\
\hline
\end{tabular}

Table 2 Cutting condition of urethane foam

\begin{tabular}{c|c}
\hline Depth of cut & $1 \mathrm{~mm}$ \\
\hline Feed rate & $40 \mathrm{~mm} / \mathrm{min}$ \\
\hline Spindle speed & $4000 \mathrm{~min}-1$ \\
\hline Cutting tool & 2-flute square endmill of $\varphi 6 \mathrm{~mm}$ \\
\hline
\end{tabular}
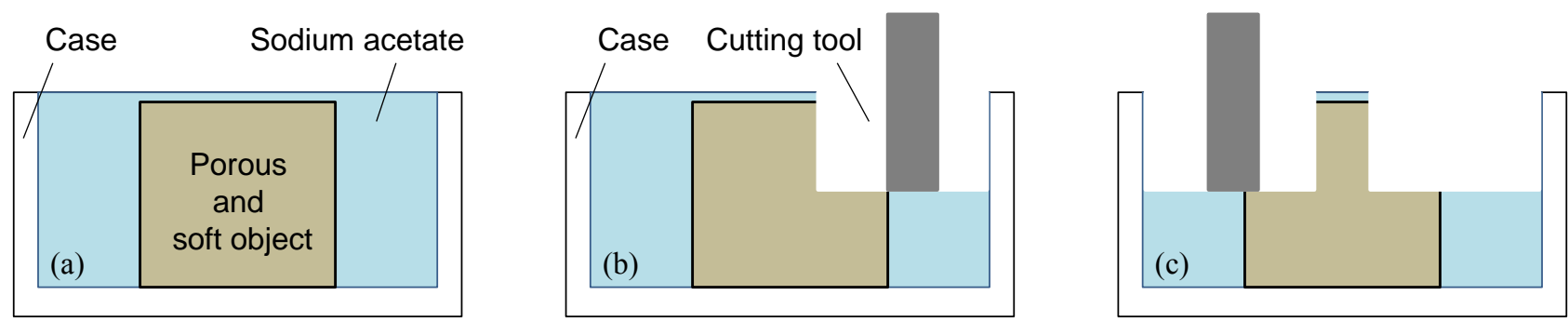

Fig. 4 Wall machining procedure by using sodium acetate

ウレタンフォームは極めて柔軟で容易に変形し, また表面にも細孔があるために形状測定が難しい. そのため, 加工結果の写真を撮影し，同一平面上に固定した定規と比較して加工形状を評価した．壁の厚さを両端と中央の 
3 点で測定した平均を表 3 に示寸が, アップカットで加工した方が, ダウンカットと比べ目標に近い寸法で加工 できていることがわかる．また，酢酸ナトリウムを用いずに加工した場合では，1 $\mathrm{mm}$ の壁は形作ることも困難 であり， $2 \mathrm{~mm}$ の壁加工においても酶酸ナトリウムを用いた場合と比べ著しく加工精度が低下している.

Table 3 Mesured thickness of wall

\begin{tabular}{c|c|c|c}
\hline \multirow{2}{*}{$\begin{array}{c}\text { Nominal } \\
\text { thickness } \\
\text { of wall }\end{array}$} & \multicolumn{3}{|c}{ Mesured thickness [mm] } \\
\cline { 2 - 4 } & Down cut & Up cut & $\begin{array}{c}\text { Without sodium } \\
\text { acetate aq. }\end{array}$ \\
\hline 1.00 & 6.52 & 1.04 & - \\
\hline 2.00 & 2.30 & 1.97 & 4.57 \\
\hline & & \\
\hline & & \\
\hline
\end{tabular}

(a) Down cut

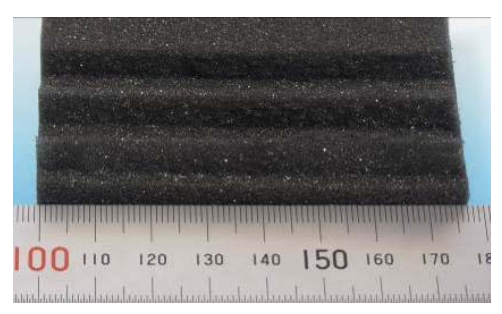

(b) Up cut

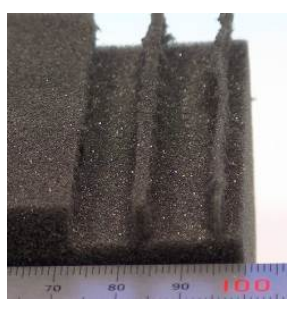

Fig. 5 Machined results of urethane foam

図 5 に加工された壁形状の写真を示す，それぞれ，左が壁の正面から，右が側面からの写真である. 正面に向 かって下の壁が厚さ $1 \mathrm{~mm}$ ，上の壁が厚さ $2 \mathrm{~mm}$ を目標に加工したものである. ダウンカットで加工したウレタン フォームでは，特に剛性の低下寸る壁の上部で多くのバリが見られる. ダウンカットでは一般に切れ刃が工作物 に切り込む際に大きな切削抵抗が生じるため, 柔軟なウレタンフォームでは加工精度が極端に悪化したものと思 われる．また，壁の厚さが大きくなることでウレタンフォームの壁の岡性が高くなり，結果として加工精度が向 上していることがわかる.

以上のことから，多孔質・柔軟工作物では，内部の無数の細孔に酢酸ナトリウム水溶液が浸透することで，内 部からの保持が可能となり，加工中の切削力による変形も低減できることが分かる.

\section{4. 多孔質 · 柔軟工作物の巧妙加工}

多孔質・柔軟工作物の巧妙加工の実現可能性を検討するために複雑形状の加工実験を行った． 5 軸制御立型マ シニングセンタ（DMG 森精機製作所 : NMV-3000DCG）を用い，多孔質・柔軟工作物として前章と同じのポリエ ステル系ウレタンフォームを対象とした。 目標形状には, 柔らかいために変形し易い形状としてのワイングラス と, 把持の難しい葉形状, 幾何学的に表現できない複雑にねじれた自由曲面を有したインペラ形状の 3 種類を用 意した.

\section{$4 \cdot 1$ ワイングラス形状の 3 軸制御加エ}

まず，図 6 に示したワイングラスのカップ部内側の荒加工と仕上げ加工を行った. 初めの荒加工を工程番号 1 とし，仕上げ加工を工程番号 2 とする. ワイングラス形状の切削条件と使用工具は表 4 の通りであり, 主軸回転 
数はいずれも $10,000 \mathrm{~min}^{-1}$ である. ワイングラスのカップ部内側を加工したあと, カップ部の剛性を保てるように 酢酸ナトリウム水溶液をカップ部内側に流し込み凝固させた，続いて，マシニングセンタの台座を $30^{\circ}$ 傾け，飲 み口の厚さが $1 \mathrm{~mm}$ ，持ち手の厚さが $3 \mathrm{~mm}$ になるようにワイングラス形状全体の外周部を加工した. この荒加工 を工程番号 3 とし，仕上げ加工を工程番号 4 とする.工程番号 2 を行った後にワイングラス形状の外周部へ酶酸

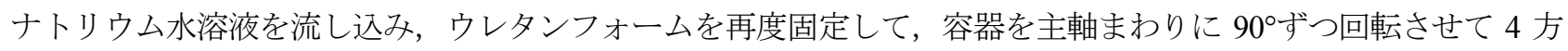
向から工程番号 3 と 4 を繰り返してワイングラス形状全体の外周部を加工した.

図 7 は加工後のワイングラス形状であるが，目標と同様の形状が得られていることがわかる.

Table 4 Ctting tools used and condition of wine glass

\begin{tabular}{c|c|c|c|c}
\hline $\begin{array}{c}\text { Process } \\
\text { No. }\end{array}$ & Tools used & $\begin{array}{c}\text { Depth } \\
{[\mathrm{mm}]}\end{array}$ & $\begin{array}{c}\text { Feed rate } \\
\text { XY- } \\
\text { direction } \\
{[\mathrm{mm} / \mathrm{min}]}\end{array}$ & $\begin{array}{c}\text { Feed rate } \\
\text { Z-direction } \\
{[\mathrm{mm} / \mathrm{min}]}\end{array}$ \\
\hline 1 & 2-flute square endmil of $\varphi 10 \mathrm{~mm}$ & 2 & 350 & 80 \\
\hline 2 & 2-flute square endmil of $\varphi 6 \mathrm{~mm}$ & 0.8 & 150 & 80 \\
\hline 3 & 2-flute square endmil of $\varphi 10 \mathrm{~mm}$ & 2 & 450 & 80 \\
\hline 4 & 2-flute square endmil of $\varphi 10 \mathrm{~mm}$ & - & 400 & 150 \\
\hline
\end{tabular}

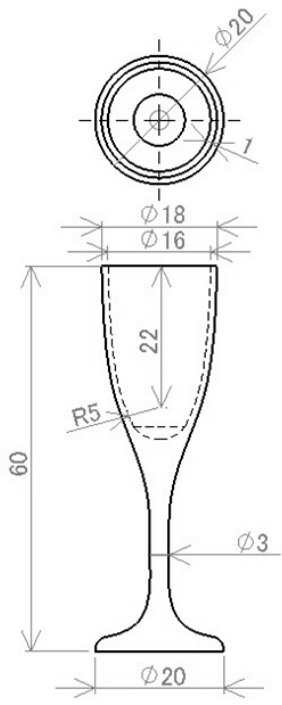

Fig. 6 Targeted wine glass shape

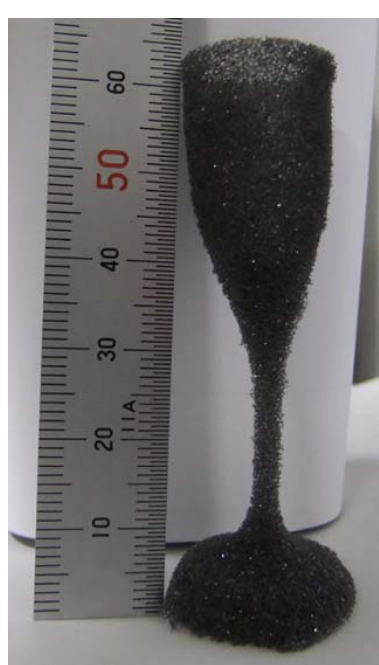

(a) Front view

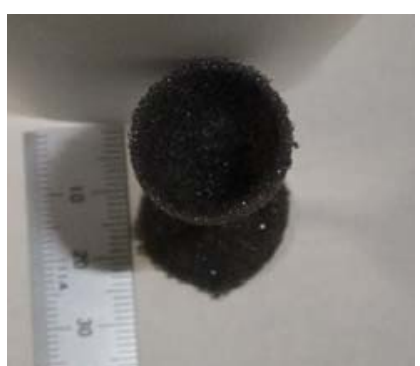

(b) Top view

Fig.7 Machined wine glass

\section{$4 \cdot 2$ 葉形状の加工}

次に, 全面が加工面となっている葉形状の加工を試みた。 ウレタンフォームの素材形状は直方体であり, 図 8 に示した葉形状は全面が加工面のため, 把持するために残しておく部分が存在しない. そこで工作物を容器内で 反転させて両面からの加工を行った. 葉形状を加工したときの切削条件と使用工具は表 5 の通りであり, 回転数 は同様に $10,000 \mathrm{~min}^{-1}$ である.

加工の手順としては， ウレタンフォームを保持しながら加工できるように，まず葉形状の凸面側を加工した. この荒加工を工程番号 1 , 仕上げ加工を工程番号 2 とする. 次に，工作物を容器から取出して凸面側が下になる ように反転させ，䣷酸ナトリウム水溶液を凝固させて再度保持した．最後に，残りの凹面側の荒加工と仕上げ加 工を行った. 反転後の位置決めにはジグを用い，工作物が反転前と同じ位置になるように配慮した． 凹面側の荒 加工を工程番号 3, 仕上げ加工を工程番号 4 とする. 
Table 5 Ctting tools used and condition of wine glass

\begin{tabular}{c|l|c|c|c}
\hline $\begin{array}{c}\text { Process } \\
\text { No. }\end{array}$ & Tools used & $\begin{array}{c}\text { Depth } \\
{[\mathrm{mm}]}\end{array}$ & $\begin{array}{c}\text { Feed rate } \\
\text { XY- } \\
\text { direction } \\
{[\mathrm{mm} / \mathrm{min}]}\end{array}$ & $\begin{array}{c}\text { Feed rate } \\
\text { Z-direction } \\
{[\mathrm{mm} / \mathrm{min}]}\end{array}$ \\
\hline 1 & 2-flute ball endmil of $\varphi 10 \mathrm{~mm}$ & 3 & 2700 & 100 \\
\hline 2 & 2-flute ball endmil of $\varphi 10 \mathrm{~mm}$ & 1 & 2000 & 150 \\
\hline 3 & 2-flute ball endmil of $\varphi 10 \mathrm{~mm}$ & 3 & 2700 & 100 \\
\hline 4 & 2-flute ball endmil of $\varphi 10 \mathrm{~mm}$ & 1 & 300 & 100 \\
\hline
\end{tabular}

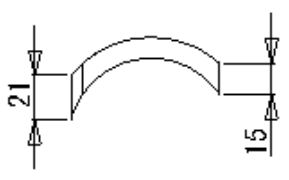

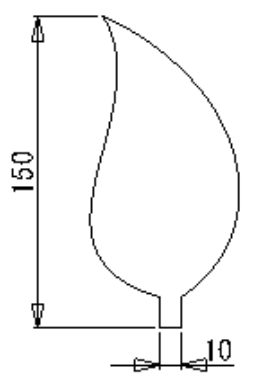

Fig.8 Targeted leaf shape to create

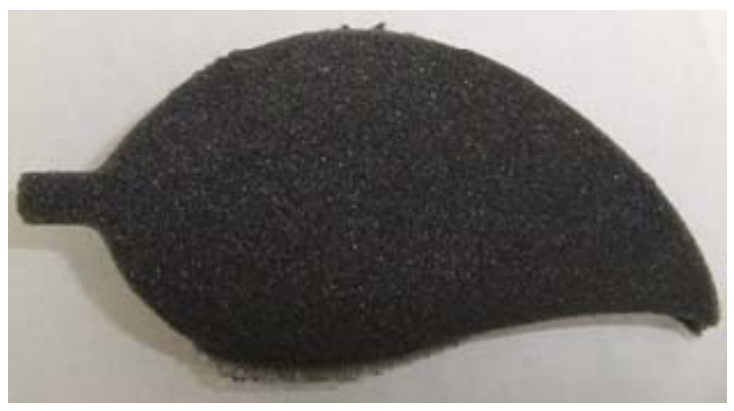

(b) Convex surface of machined leaf shape

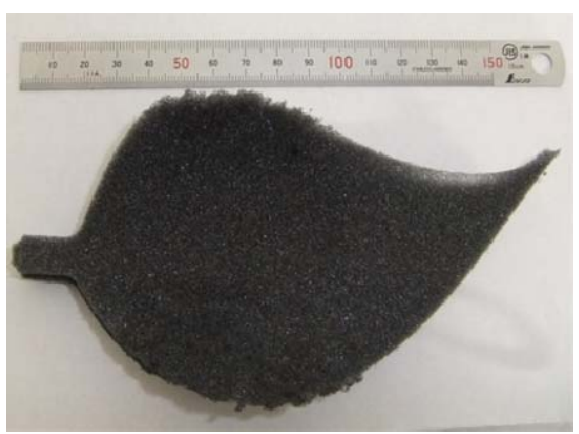

(a) Concave surface of machined leaf shape

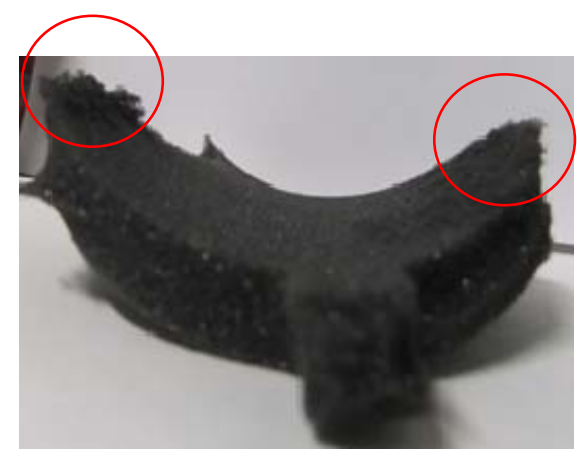

(c) Upward view of machined leaf shape

Fig.9 Machined leaf shape

困 9 はそれぞれ加工後の葉形状の外観である.䣷酸ナトリウム水溶液が浸潤しきれていない同図(c)内に囲んで 記した箇所で，工作物が変形したために削り残しが発生した。しかしながら，それ以外の箇所では良好な加工面 の葉形状が得られた.

\section{$4 \cdot 35$ 軸制御インペラ形状の加エ}

図 10 に示す直径 $100 \mathrm{~mm}$ ，高さ $50 \mathrm{~mm}$ で羽の厚さが $1 \mathrm{~mm}$ の複雑なインペラ形状を加工した.まず前節と同じ 直方体のウレタンフォームを円柱状へ, 続いて円錐状へと外形加工を行った. 初めの外形加工を工程番号 1 とし, 2 回目の外形加工を工程番号 2 とする. その後, 溝の加工を行った. この際, 良好な表面性状を得るために仕上 げ加工を 2 回行っている. 荒加工を工程番号 3，2 回の仕上げ加工をそれぞれ工程番号 4 と 5 とする. またこれら 加工開始から終了までの間，一度も酢酸ナトリウム水溶液の凝固と融解を繰り返すことなく加工を行った. 
Nakamoto, Wakamatsu and Takeuchi, Transactions of the JSME (in Japanese), Vol.81, No.825 (2015)

Table 6 Ctting tools used and condition of Impeller

\begin{tabular}{c|c|c|c}
\hline $\begin{array}{c}\text { Process } \\
\text { No. }\end{array}$ & Tools used & $\begin{array}{c}\text { Feed rate } \\
\text { XY- } \\
\text { direction } \\
{[\mathrm{mm} / \mathrm{min}]}\end{array}$ & $\begin{array}{c}\text { Spindle } \\
\text { speed } \\
{\left[\mathrm{min}^{-1}\right]}\end{array}$ \\
\hline 1 & Face mill & 5000 & 10000 \\
\hline 2 & Face mill & 5000 & 12000 \\
\hline 3 & 2-flute endmil of $\varphi 7 \mathrm{~mm}$ & 200 & 12000 \\
\hline 4 & Tapered ball endmil $\mathrm{R} 2 \times 10^{\circ}$ & 400 & 12000 \\
\hline 5 & Tapered ball endmil $\mathrm{R} 2 \times 10^{\circ}$ & 400 & 12000 \\
\hline
\end{tabular}

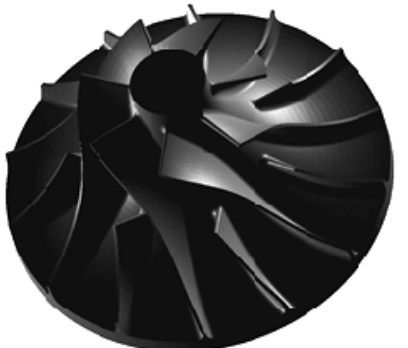

Fig.10 Targeted impeller shape to create

切削条件と使用工具は表 6 の通りであり，図 11 にインペラ加工用の工具経路を示す. 図 11 において赤い線で 示されているのが，インペラのシュラウド面からハブ面にかけて生成した工具経路であり，一般的なアルミニウ 厶合金用の切削条件を採用している。図 12 に加工中の様子を示しており，図 13 は加工後のインペラ形状の外観 である. スプリッター刃形状も高精度に加工できていることが分かる.ただし, 工作物の薄いところでは切削温度 の影響を受けやすく, 酢酸ナトリウムが溶けはじめたためにインペラ先端部などでバリが生じたと考えられる.

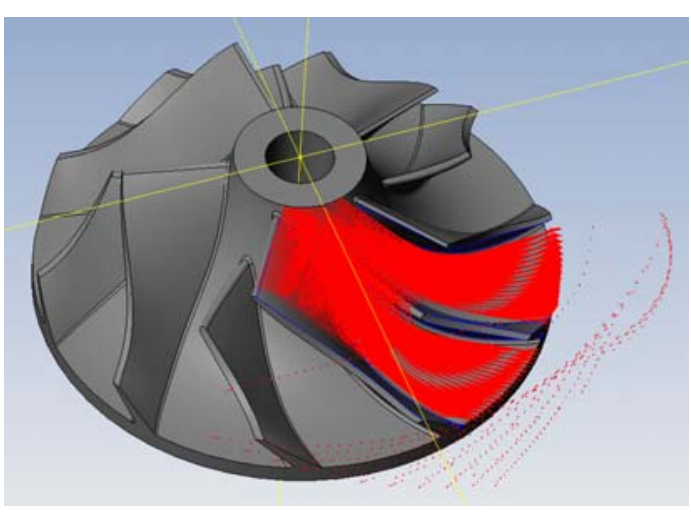

Fig.11 Generated tool paths for making impeller

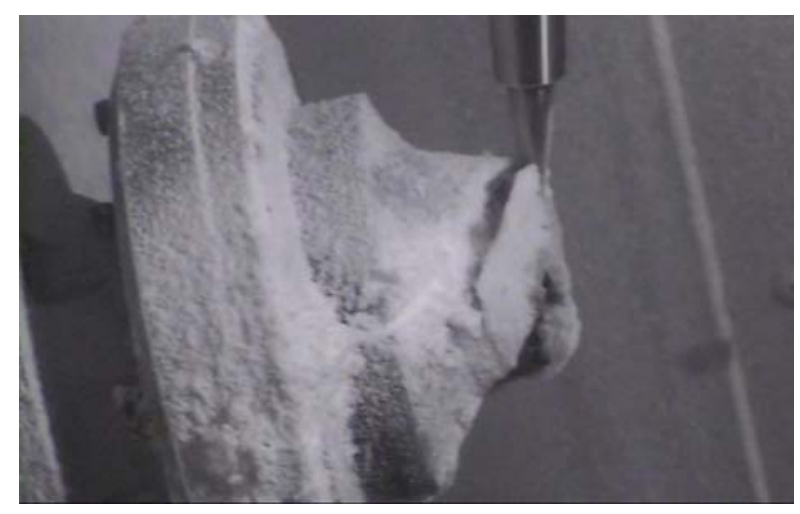

Fig.12 An appearance during machining impeller

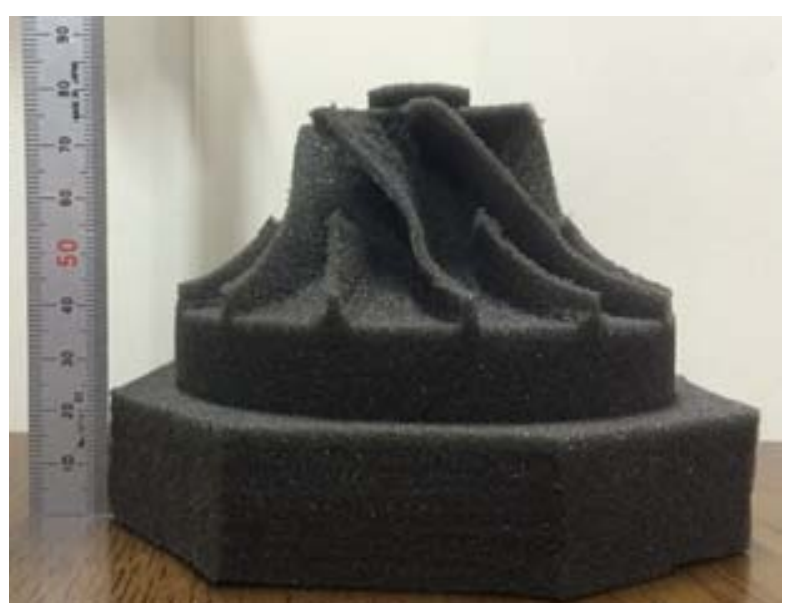

(a) Front view

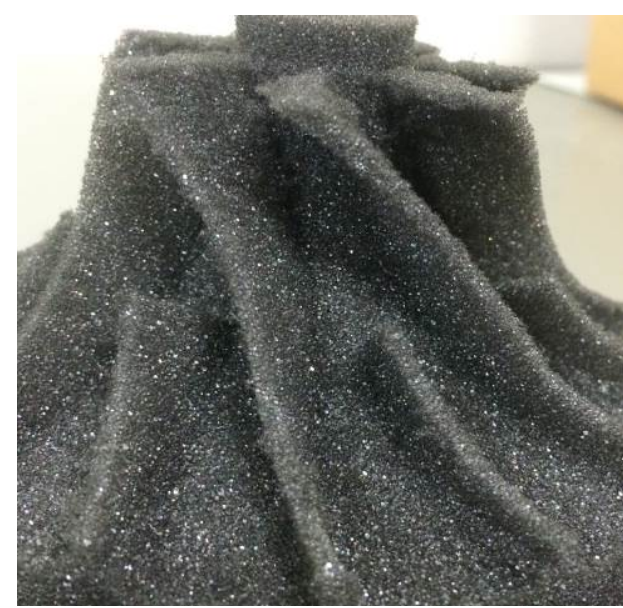

(b) Detail of machined impeller

Fig.13 Machined impeller 


\section{5. 結 言}

スポンジ等の有機高分子を主成分とする多孔質の柔軟工作物は，ゴム等の無孔質の柔軟工作物とは異なり，内 部に無数の細孔を持つ. そのため, 外部からの把持や保持では, 加工時の変形や把持に起因寸る変形が発生し, 高精度な切削加工を実現することは難しい，そこで本研究では，多孔質材が液体を含浸できることに着目し，酢 酸ナトリウム水溶液を用いた工作物把持手法を応用することで, 多孔質材の内部からの保持によってみかけ上の 剛性が確保され高精度に複雑形状を加工できることを確認した.

\section{謝 辞}

本研究の一部は, 平成 26 年度科学研究費補助金（挑戦的萌芽研究 26630022）のもとに行われたことを記す. また, 本研究における加工実験を実施するにあたり DMG 森精機(株), 東京農工大学 学生 安藤潤人氏, 中部大 学 学生 佐合仁史氏, 山中 薰氏, 岡田皓也氏, 杉山卓也氏の協力を得た. ここに記して感謝の意を表す.

\section{文献}

濱田大地, 中本圭一, 石田 徹, 竹内芳美, 入れ子を有する複雑形状の巧妙加工, 日本機械学会論文集 C編, Vol. 77, No. 780 (2011), pp. 3127-3136.

Kakinuma, Y., Kidani, S., and Aoyama, T., Ultra-precision Cryogenic Machining of Viscoelastic Polymers, CIRP Annals -Manufacturing Technology, Vol. 61, Issue. 1 (2012), pp. 79-82.

夏目矩行, 中本圭一, 石田 徹, 竹内芳美, 複数の曲がり円柱からなる複雑形状の巧妙加工, 日本機械学会論文集

C編, Vol. 78, No. 786 (2012), pp. 697-706.

中本圭一, 植地亮太, 竹内芳美, 把持の難しい柔軟工作物の巧妙加工, 日本機械学会論文集C編, Vol. 79, No. 808 (2013), pp. 10-17.

小原治樹, 渡邊隆博, 大住 剛, 羽多野正俊, 二宮英治, 3次元薄板加工技術の開発, 精密工学会誌, Vol. 69, No. 3 (2003), pp. 375-379.

寺本孝司, 黒石雄一, 山下正敬, 柔軟弾性体のエンドミル加工に関寸る研究, 日本機械学会 生産システム部門研 究発表講演会講演論文集 (2009), pp. 89-90.

\section{References}

Hamada, D., Nakamoto, K., Ishida, T. and Takeuchi, Y., Dexterous machining for a complicated shape with nested structure, Transactions of the Japan Society of Mechanical Engineers, Series C, Vol. 77, No. 780 (2011), pp. 3127-3136 (in Japanese).

Kakinuma, Y., Kidani, S. and Aoyama, T., Ultra-precision cryogenic machining of viscoelastic polymers, CIRP Annals -

Manufacturing Technology, Vol. 61, Issue. 1 (2012), pp. 79-82.

Natsume, N., Nakamoto, K., Ishida, T. and Takeuchi, Y., Dexterous machining of complicated shape consisting of several bended columns, Transactions of the Japan Society of Mechanical Engineers, Series C, Vol. 78, No. 786 (2012), pp. 697-706 (in Japanese).

Nakamoto, K., Ueji, R. and Takeuchi, Y., Dexterous machining of soft objects difficult to clump, Transactions of the Japan Society of Mechanical Engineers, Series C, Vol. 79, No. 808 (2013), pp. 10-17 (in Japanese).

Obara, H., Watanabe, T., Ohsumi, T., Hatano, M. and Ninomiya, E., A method to machine three - dimensional thin parts, The Japan Society for Precision Engineering, Vol. 69, No. 3 (2003), pp. 375-379 (in Japanese).

Teramoto, K., Kuroishi, Y. and Yamashita, M., A fundamental framework for elastomer machining, Proceedings of the Manufacturing Systems Division Conference Annual Meeting (2009), pp. 89-90 (in Japanese). 